\title{
PENINGKATAN KEWIRAUSAHAAN PADA ANGGOTA PKK RT 2 RW 9 DUSUN KLANDUNGAN DESA LANDUNGSARI KECAMATAN DAU KABUPATEN MALANG
}

\author{
Diana Eka ${ }^{1}$, Achmad Zaini ${ }^{2}$, Tri Wahyu Widodo ${ }^{3}$, Asminah Rachmi $^{4}$ \\ 1,2,3,4 Jurusan Administrasi Niaga, Politeknik Negeri Malang
}

\begin{abstract}
Abstrak
Pelaksanakan kegiatan sehari-hari, para anggota PKK di RT 2 RW 9 Dusun Klandungan Desa Landungsari Kecamatan Dau Kabupaten Malang masih banyak yang belum melakukan kegiatan yang produktif yang menghasilkan uang. Para anggota PKK belum melakukan kegiatan kewirausahaan secara berkelompok. Kalaupun ada beberapa anggota secara individu memiliki usaha sendiri berupa toko. Untuk membantu memperoleh pendapatan tambahan untuk rumah tangga para anggota PKK perlu melakukan kegiatan kewirausahaan yang produktif dan mudah dilakukan dirumah.

Beberapa masalah yang timbul di PKK RT2 RW 9 Dusun Klandungan Desa Landungsari berkaitan dengan kewirausahaan antara lain: tidak adanya bekal jiwa kewirausahaan, tidak adanya kemampuan/keterampilan kewirausahaan, tidak adanya pembina lapangan yang membimbing berwirausaha, tidak adanya modal untuk berwirausaha.

Pelatihan diperlukan untuk mengatasi permasalahan yang terjadi di PKK RT2 RW 9 Dusun Klandungan Desa Landungsari dalam kewirausahaan. Pelatihan yang perlu dilaksanakan tentang kewirausahaan meliputi : peningkatan motivasi berwirausaha, pemberian keterampilan kewirausahaan, pendampingan dengan kerjasama dengan pembimbing lapangan yang kompeten, bantuan modal/peralatan berwirausaha.

Politeknik Negeri Malang sebagai bagian dari masyarakat, yang merupakan lembaga pendidikan tinggi, dengan salah satu tugasnya adalah meningkatkan kualitas sumber daya manusia melalui jalur Pengabdian Masyarakat berkewajiban untuk memberikan bantuan pembimbingan kepada para anggota PKK di RT 2 RW 9 Dusun Klandungan Desa Landungsari Kecamatan Dau Kabupaten Malang
\end{abstract}

Kata kunci - Kewirausahaan, PKK, Motivasi, Keterampilan, Klandungan

\section{PENDAHULUAN}

$\mathrm{B}$ akat kewirausahaan dan lingkungan memiliki pengaruh positif terhadap perilaku dan sikap kewirausahaan, orang lahir tidak dengan sikap tertentu, orang harus belajar terlebih dahulu untuk bersikap dengan cara tertentu. Oleh karena itu orang bisa berperilaku kewirausahaan karena pengaruh bakat kewirausahaan dan faktor-faktor lingkungan, meskipun sikap kewirausahaan masing-masing individu bisa berbeda. Bakat kewirausahaan yang dipunyai seseorang tidak dapat dijadikan jaminan untuk mengembangkan sikap kewirausahaan. Ada yang menganggap bahwa pengembangan lebih mudah, karena didorong oleh lingkungannya yang sudah terbiasa melakukan pengembangan. Namun demikian ada juga yang tidak berperilaku demikian karena tidak pernah mempunyai pengalaman atau tidak terbiasa dengan lingkungan kewirausahaan.

Sangat penting untuk memberi dukungan kepada organisasi sosial seperti PKK agar semua anggotanya memiliki jiwa kewirausahaan sehingga mampu berkembang 
secara ekonomi. Dalam mewujudkan misinya organisasi ini perlu didukung oleh berbagai pihak baik dari dalam maupun luar organisasi. Sikap kewirausahaan pada organisasi sosial yang menghimpun para ibu di di wilayah Rukun Tetangga berbeda-beda. Organisasi yang merupakan ujung tombak pendorong peningkatan kesejahteraan masyarakat di tingkat paling bawah ini mempunyai peran penting untuk membentuk sikap kewirausahaan para anggotanya. Dukungan dari dalam tidak cukup dengan semangat dan rasa memiliki yang tinggi dari para anggota organisasi, tetapi kemampuan untuk mengembangkan kesejahteraan secara baik juga sangat diperlukan. Anggota organisasi PKK pada umumnya terdiri dari para ibu yang sebagian besar merupakan ibu rumah tangga yang belum mempunyai usaha yang dapat ikut meningkatkan kesejahteraan keluarga. Oleh karena itu akan sangat bermanfaat sekali jika para ibu mempunyai usaha kecil-kecilan yang bisa digunakan untuk meningkatkan ekonomi.

Kegiatan para ibu RT 2 RW 9 Dusun Klandungan Desa Landungsari Kabupaten Malang sehari-harinya selain bekerja sebagai ibu rumah tangga juga bekerja di sawah atau pekarangan untuk membantu suami. Kegiatan tersebut akan lebih produktif jika diarahkan pada kegiatan yang menghasilkan uang seperti kegiatan kewirausahaan. Pada saat ini, kewirausahaan banyak dilakukan di berbagai tempat, bahkan sampai ke pelosok desa dengan cara berbeda-beda, dengan hasil cukup menguntungkan. Tidak kalah pentingnya dalam berwirausaha adalah memperhitungkan biaya usaha. Dengan perhitungan biaya usaha yang tepat maka dapat diharapkan usaha yang dilakukan dapat mendatangkan keuntungan.

\section{LOKASI DAN METODE PENGABDIAN KEPADA MASYARAKAT (PkM)}

PkM dilakuka di Dusun Klandungan,
Desa Landungsari, Kecamatan Dau, Kabupaten Malang. Dilakukan dengan metode alih pengetahuan, diskusi, pemberian wawasan kewirausahaan dan pelatihan hidroponik sebagai solusi pemilihan kewirausahaan oleh ibu-ibu PKK.

\section{PEMBAHASAN}

Berdasarkan identifikasi masalah yang meliputi: kurangnya dukungan lingkungan RT 2 RW 9 Desa Landungsari dalam berwirausaha, kurangnya motivasi berwirausaha Ibu-ibu PKK RT 2 RW 9, Dsn. Klandungan, Desa Landungsari, Kecamatan Dau, Kabupaten Malang, serta kurangnya pengetahuan jenis wirausaha yang dapat diterapkan dilingkungan sekitar, maka diajukan solusi pemecahan masalah sebagai berikut :

Berdasarkan pilihan berbagai jenis usaha yang ditawarkan dalam pelatihan dengan disertai diskusi bersama Ibu-ibu PKK RT 2 RW 9, Dsn. Klandungan, Desa Landungsari, Kecamatan Dau, Kabupaten Malang disepakati bahwa usaha yang mampu dikerjakan dengan kompetensi mereka dan tidak membutuhkan modal besar adalah usaha hidroponik, Ibu-ibu PKK RT 2 RW 9, Dsn. Klandungan, Desa Landungsari, Kecamatan Dau, Kabupaten Malang menganggap usaha hidroponik sesuai dengan pengalaman mereka dibidang cocok tanam. Alternatif berwira usaha hidroponik sesuai dengan kondisi lingkungan para ibu-ibu dengan sebagian besar keluarga mereka adalah petani. Pemilihan teknik hidroponik diterapkan untuk mengatasi permasalahan berkurangnya lahan pertanian yang mereka miliki.

Keunggulan metode hidroponik adalah kemudahan dan kemungkinan bisa dipasarkan dengan lebih baik, mengingat kesadaran masyarakat untuk mengkonsumsi makanan sehat. Disamping bisa digunakan untuk berwira usaha, hasil dari kegiatan ini juga bisa dikonsumsi sendiri untuk meningkatkan ketahanan daya tahan menghadapi pandemi yang sedang berlangsung.

Budi daya hidroponik menggunakan air/larutan mineral bernutrisi yang dipakai tanaman dan bahan lain sebagai pengganti tanah. Bahan pengganti tanah mengandung unsur hara, seperti sabut kelapa, serat mineral, pasir, pecahan genteng/batu bata, serbuk kayu, $\&$ lain sebagainya.

Pelaksanaan pelatihan kewirausahaan hidroponik dilaksanakan dengan dihadiri para ibu PKK RT 2 RW 9 Desa Landungsari Kecamatan Dau Malang. Pembina dan pengarah dari Politeknik Negeri Malang juga hadir sebagai nara sumber pengetahuan kewirausahaan. Dalam kesempatan ini juga 
diundang hadir Bapak Gaguk, seorang praktisi usaha hidroponik yang telah berhasil mengembangkan tanamannya dengan baik dan menguntungkan. Bapak Gaguk bertindak sebagai narasumber praktek kewirausahaan hidroponik.

Dalam praktek tersebut diaplikasikan secara langsung cara menyiapkan benih tanaman, cara meracik nutrisi tanaman serta cara merawat tanaman hingga nantinya tumbuh dengan baik. Sebelum pelatihan di mulai Ibu Diana sebagai ketua tim PKM Polinema menyampaikan sambutan sekaligus menjelaskan tujuan kegiatan ini diadakan. Dalam sambutannya ketua tim PKM menyampaikan bahwa tujuan kegiatan ini untuk memotivasi para Ibu-ibu PKK RT 2 RW 9, Dsn. Klandungan, Desa

Landungsari, Kecamatan Dau, Kabupaten Malang untuk berwirausaha dan memberikan alternatif jenis kewirausahaan yang sesuai dengan kondisi RT 2 RW 9 serta mendukung pengadaan gizi mandiri bagi rumah tangga.

Setelah ketua tim PKM Polinema menyampaikan sambutan kegiatan dilanjutkan dengan penjelasan praktisi hidroponik Bapak Gaguk. Dalam penjelasannya Bapak Gaguk mengatakan bahwa bisnis hidroponik saat ini sangat menjanjikan. Pengerjaannya juga sangat mudah sehingga dapat dilakukan sebagai hobi yang menyenangkan. Praktek dimulai dengan kegiatan pembuatan benih pada wadah yang disediakan.

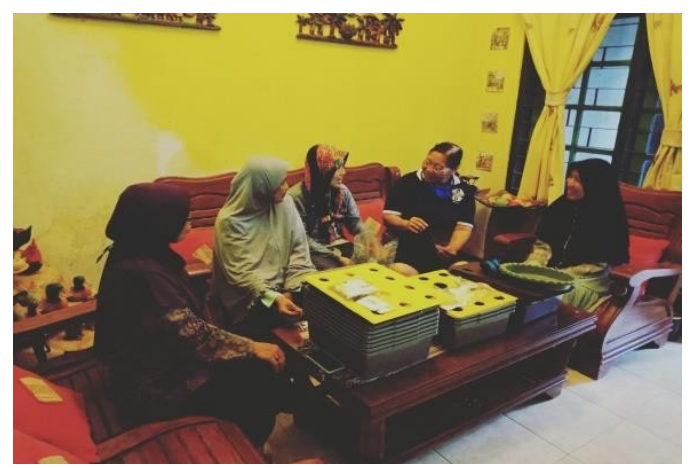

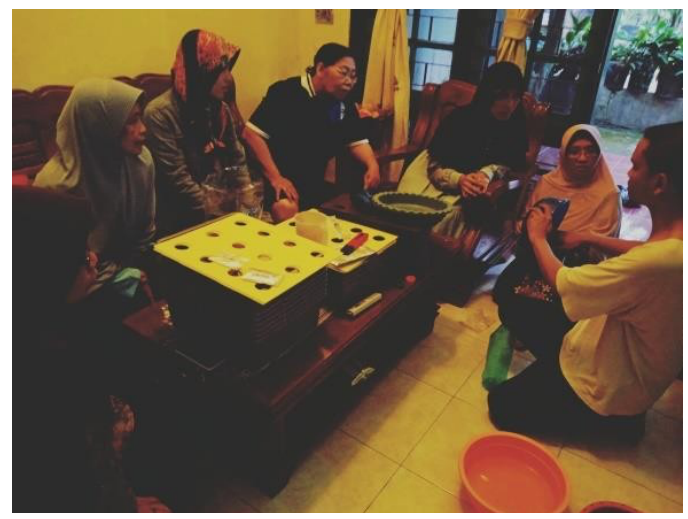

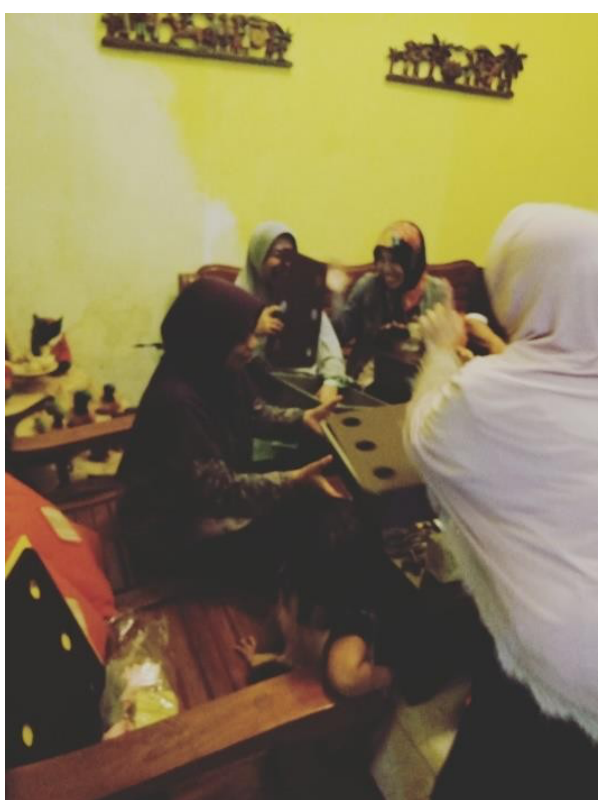

Dalam praktek ini para peserta banyak melakukan diskusi dan mengajukan pertanyaan sehingga kegiatan berjalan informatif, komunikatif, dan interaktif. Selanjutnya praktek diteruskan dengan pembuatan racikan nutrisi yang dicampur dari berbagai bahan yang tersedia. Racikan nutrisi yang sudah jadi akan menjadi inti ramuan yang diambil sedikit- sedikit setiap hari dengan dicampur air untuk memberi nutri pada tanaman. Dalam kegiatan ini para peserta juga bebas mengajukan pertanyaan dan diskusi dengan narasumber sehingga materi yang disampaikan dapat dimengerti dengan baik oleh seluruh peserta.

Setelah praktek rangkaian pembuatan media, bibit dan nutrisi disampaikan oleh narasumber maka giliran para peserta melakukan praktek sendiri dengan panduan narasumber. Dengan diskusi dan tanya jawab maka semua peserta dapat memahami materi 
dengan baik. Pada akhir pelatihan para peserta diberi satu perangkat media hidroponik yang terdiri dari: wadah plastik, netpot, kain flanel, bibit tanaman, pupuk nutrisi.

\section{KESIMPULAN DAN SARAN}

Toko Rejeki Mrajak merupakan UMKM yang bergerak di bidang ritel dengan Ibu PKK

Ibu PKK RT 2 RW 9 Dsn. Klandungan, Desa Landungsari Kecamatan Dau Kabupaten Malang membutuhkan wadah untuk memberdayakan diri dan berwirausaha. Dimana dengan wadah tersebut dapat bekerjasama dan berkomunikasi serta menjaga kerukunan dan meningkatkan pendapatan dan kesejahteraan anggotanya. Selain itu juga sebagai ujung tombak pelaksanaan 10 program pokok PKK yang berkarya untuk membantu pemenuhan gizi keluarga secara mandiri terlebih untuk menjaga dan meningkatkan imunitas tubuh menghadapi pandemik Covid 19.

Saran yang dapat diberikan Perlu dilakukan pendampingan kegiatan wirausaha PKK RT 2 RW 9 secara berkesinambungan oleh pemerintah Desa, dengan melakukan pengembangan kegiatan wirausahaan yang lebih variatif sesuai potensi warga. Perlu melakukan studi banding pada kelompok usaha dari PKK wilayah lain

\section{DAFTAR PUSTAKA}

Firmansyah, Adi, 2019, Etalase Bisnis Pengertian Kewirausahaan, Jenis dan Contohnya, Etalase Bisnis.com, diakses 10 Oktober 2020

Sumber Plastik, Sistem Hidroponik Sederhana Sumber Plastik.co.id 2018 